\title{
SYNTHETIC-PITCH BINDERS BY AUTOCLAVE POLYMERIZATION OF ORGANICS
}

W. E. Smith

B. Napier, Jr

June 1976

\section{UNION CARBIDE}

OAK RIDGE Y-12 PLANT OAK RIDGE, I LNNESSt

prepared for the U.S. ENERGY RESEARCH AND DEVELOPMENT ADMINISTRATION under U.S. GOVERNMENT Contract W-7405 eng 26

\section{MASTER}




\section{DISCLAIMER}

This report was prepared as an account of work sponsored by an agency of the United States Government. Neither the United States Government nor any agency Thereof, nor any of their employees, makes any warranty, express or implied, or assumes any legal liability or responsibility for the accuracy, completeness, or usefulness of any information, apparatus, product, or process disclosed, or represents that its use would not infringe privately owned rights. Reference herein to any specific commercial product, process, or service by trade name, trademark, manufacturer, or otherwise does not necessarily constitute or imply its endorsement, recommendation, or favoring by the United States Government or any agency thereof. The views and opinions of authors expressed herein do not necessarily state or reflect those of the United States Government or any agency thereof. 


\section{DISCLAIMER}

Portions of this document may be illegible in electronic image products. Images are produced from the best available original document. 
Reference to a company or product name does not imply approval or recommendation of the product by Union Carbide Corporation or the U.S. Energy Research and Development Administration to the exclusion of others that may meet specifications.

Printed in the United States of America. Available from

National Technical Information Service

U.S. Department of Commerce

5285 Port Royal Road, Springfield, Virginia 22161

Price: Printed Copy \$4.00; Microfiche \$2.25

This report was prepared as an account of work sponsored by the United States Government. Neither the United States nor the Energy Research and Development Administration/United States Nuclear Regulatory Commission, nor any of their employees, nor any of their contractors, subcontractors, or their employees, makes any warranty, express or implied, or assumes any legal liability or responsibility for the accuracy, completeness or usefulness of any information, apparatus, product or process disclosed, or represents that its use would not infringe privately owned rights. 
Date of Issue: June 28, 1976

Distribution Category: UC-25

\title{
SYNTHETIC-PITCH BINDERS BY AUTOCLAVE POLYMERIZATION OF ORGANICS
}

\author{
W. E. Smith \\ B. Napier, Jr
}
Chemistry Development Department $Y$-12 Development Division

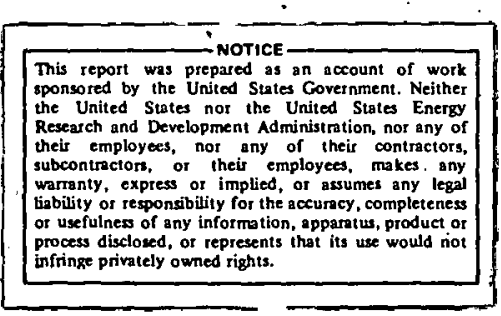

Oak Ridge Y-12 Plant

P. O. Box Y, Oak Ridge, Tennessee 37830

\footnotetext{
Prepared for the US Energy Research and Development Administration
}

Under US Government Contract W-7405-eng-26 


\begin{abstract}
Polymers prepared by autoclave heat treatment of simple hydrocarbons were evaluated as sources of synthetic pitches for use in fabricating composite carbons. Hydrocarbons included: indene, phenanthrene, triphenylbenzene, 1,4-diphenyl-1,3-butadiyne, and cinnamylideneindene. Autoclave temperatures and pressures were in the ranges of 340 to $515^{\circ} \mathrm{C}$ and 5 to $28 \mathrm{MPa}$, respectively. The more promising pitch materials were liquids or low-melting solids with coke yields of approximately 50 weight percent. Binary mixtures of organics were able to produce polymers and resulting carbons with properties that were correlated to the composition of the organic blend, thus allowing the controlled modification of properties.
\end{abstract}




\section{CONTENTS}

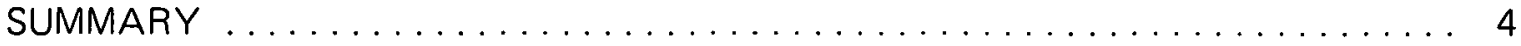

INTRODUCTION ....................................... 5

SYNTHETIC-PITCH BINDERS ............................ 6

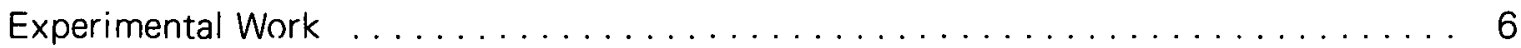

Materials ................................... 6

Equipment ................................... 7

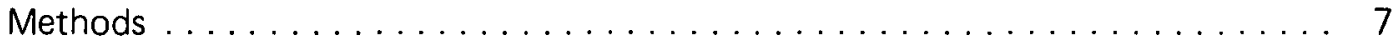

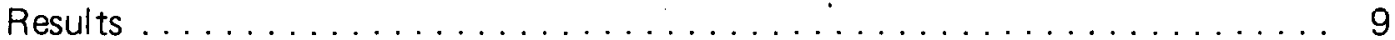

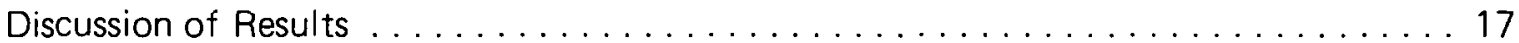

Conclusions and Recommendations ........................... 22

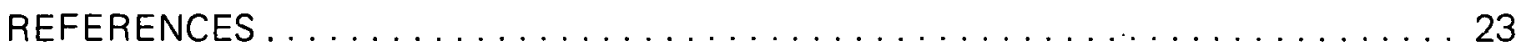




\section{SUMMARY}

Production of useful synthetic pitch materials by autoclave polymerization of hydrocarbons was evaluated. Autoclave temperatures were from 340 to $515^{\circ} \mathrm{C}$ and pressures were from 5 to $28 \mathrm{MPa}$. Hydrocarbons included: indene, phenanthrene, triphenylbenzene, mixtures of indene and triphenylbenzene, and mixtures of cinnamylideneindene and 1,4-diphenyl-1,3buțadiyne.

Promising synthetic pitch precursors to graphitic carbons were produced from indene and phenanthrene. The products were high-viscosity fluids or low-melting solids having coke yields of approximately 50 wt \%.

Triphenylbenzene produced thermoplastic polymers that are precursors to nongraphitic carbon. The most usable product melted at approximately $100^{\circ} \mathrm{C}$ and had a coke yield of approximately 50 wt \%.

Both of the binary mixtures yielded carbons with properties that correlated well with the composition of the mixtures. Indene/triphenylbenzene mixtures vielded low-melting snlins (</UUं () having coke yields of 40.45 wt \%. Melting points and coke yields of cinnamylideneindene/1,4-diphenyl-1,3-butadiyne mixtures increasen with the increasing content of 1,4-diphenyl-1,3-butadiyne. Carbons from each of the binary systems ranged from highly graphitic to nongraphitic, depending on the initial composition of the organic blend. 


\section{INTRODUCTION}

The major goal of this study was to upgrade the quality of materials used in the fabrication of composite carbon. This work was conducted at the Oak Ridge $Y-12$ Plant. (a) At present, most carbon fabrication schemes use fossil-fuel derivatives as precursor materials; and, though such materials have, to date, been abundant and inexpensive, they have the distinct disadvantage of being quite variable in their properties. Somewhat better control of precursor and carbon properties could be achieved by converting well-characterized starting materials into pitch-like polymers by a reproducible process. Ideally, relatively pure, simple hydrocarbon compounds can serve as starting materials, and can represent the concept evaluated in this study.

(a) Operated by the Union Carbide Corporation's Nuclear Division tor the US Energy Research and Development Administration. 


\section{SYNTHETIC-PITCH BINDERS}

\section{EXPERIMENTAL WORK}

\section{Materials}

Principal materials used in this study and some of their pertinent data are:

Indene $(\mathrm{CgH} 8)$

Manufacturer - Henley and Company

Purity - 90\%

Boiling Point $-180-185^{\circ} \mathrm{C}$

Molecular Weight - 116

Formula -

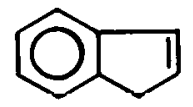

1,3,5-Triphenylbenzene $\left(\mathrm{C}_{24} \mathrm{H}_{18}\right)$

Manufacturer - Aldrich

Purity - 97\%

Melting Point $-172-174^{\circ} \mathrm{C}$

Molecular Weight - 306

Formula -<smiles>c1ccc(-c2cc(-c3ccccc3)cc(-c3ccccc3)c2)cc1</smiles>

Cinnamylideneindene $\left(\mathrm{C}_{18} \mathrm{H}_{14}\right)$

Manufacturer - UCC-ND, Y-12 Plant (1 - 3)

Purity - .> 85\%; 71 ppm $K_{1}(4)$

Melting Point - $188-192^{\circ} \mathrm{C}$

Molecular Weight - 230

Formula -<smiles>C=CC=C1C=Cc2ccccc21</smiles><smiles>Cc1ccccc1</smiles> 
1,4-Diphenyl-1,3-butadiyne $\left(\mathrm{C}_{16} \mathrm{H}_{10}\right)$

Manufacturer - UCC-ND, Y-12 Plant

Purity - $>90 \%$

Melting Point $-71-76^{\circ} \mathrm{C}$

Molecular Weight - 202

Formula -

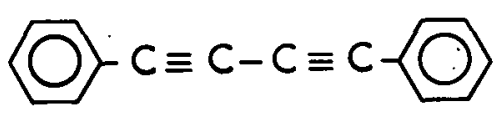

Phenanthrene $\left(\mathrm{C}_{14} \mathrm{H}_{10} \mathrm{O}\right.$

Manufacturer - Eastman

Purity - $90 \%$

Melting Point - $99-100^{\circ} \mathrm{C}$

Molecular Weight - 178

Formula -

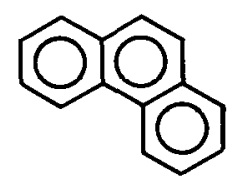

\section{Equipment}

Two autoclaves were used in the thermal polymerization studies. Data concerning the autoclaves can be summarized as follows:

\section{Autoclave $1 \quad$ Autoclave, 2}

Volume $\left(\mathrm{cm}^{3}\right)$

Maximum temperature $\left({ }^{\circ} \mathrm{C}\right)$

Maximum pressure (MPa)

$\begin{array}{lll}\text { At } 25^{\circ} \mathrm{C} & 41 & 52 \\ \text { At } 340^{\circ} \mathrm{C} & 21 & - \\ \text { At } 600^{\circ} \mathrm{C} & - & 35\end{array}$

Resistance heating was used for both vessels and Chromel-Alumel thermocouples were used to monitor the temperature. Pressures were read directly from a gage.

\section{Methods}

Polymerization - Polymerization was accomplished in the following steps:

1. Organic sample was contained in a metal can which was placed, uncapped, in the pressure vessel.

2. Vessel was purged with argon, then backfilled to a designated argon pressure. 
3. Vessel was heated to temperature and maintained for the designated hold time.

4. Product was removed on cooling.

Analytical - Characteristics of the polymers were determined as follows:

1. Melting temperatures were determined visually on a Fisher-Johns melting-point block.

2. Viscosities were measured using the Brookfield viscometer.

3. Benzene insolubles were determined by digesting 20 -gram samples in $200 \mathrm{~cm} .3$ of benzene for two hours. Insolubles were cullected by filtration, washed with $100 \mathrm{~cm}^{3}$ benzene, and allowed to dry at $25^{\circ} \mathrm{C}$ for 16 hours.

4. Molecular size distributions were determined by using gel-permeation chromatography (GPC) on tetrahydrofuran solutions of the respective products.

5. Isotruxene contents in the benzene insoluble fractions were determined by using ultraviolet spectroscopy.

6. Proton distributions were determined by nuclear magnetic resonance (NMR) spectroscopy on carbon tetrachloride solutions of the respective products.

7. Microstructures were studied from photomicrographs of the polished surfaces.

8. Interlayer spacings in graphite materials were obtained from X-ray crystallographic measurements.

Carbonization - Carbonization was achieved by observing the following parameters:

$\begin{array}{ll}\text { Sample Weight } & 10 \text { grams } \\ \text { Crucible Type } & \text { stainless steel } \\ \text { Crucible Size } & 60 \mathrm{~cm}^{3} \\ \text { Atmosphere } & \text { argon } \\ \text { Temperature (max) } & 900^{\circ} \mathrm{C} \\ \text { Coke Yield (\%) } & \begin{array}{l}\text { residuial weight after carbonization } \times 100 \text { divided by initial } \\ \text { weight. }\end{array}\end{array}$

Graphitization - Graphitization was achieved by observing the following parameters:

$\begin{array}{ll}\text { Sample Weight } & \sim 2 \text { grams } \\ \text { Crucible Type } & \text { carbon } \\ \text { Crucible Size } & 6 \mathrm{~cm}^{3} \\ \text { Atmosphere } & \text { argon } \\ \text { Temperature (max) } & 2800^{\circ} \mathrm{C}\end{array}$




\section{Results}

Indene - Synthetic-pitch materials were prepared by the autoclave polymerization of indene (400-gram samples) in the temperature range of $400-485^{\circ} \mathrm{C}$. In the as-recovered state, the products were fluid at laboratory temperatures. Data on several autoclave runs are given in Table. 1. Figure 1 better shows the correlations between polymer properties and the autoclave heat-treatment temperature (HTT), and indicates that most of the changes in properties occur after $450^{\circ} \mathrm{C}$. While pressure and coke-yield values were linear with respect to the HTT in the range of $450-485^{\circ} \mathrm{C}$, abrupt changes in viscosity and the benzene-insoluble values occurred at $470-475^{\circ} \mathrm{C}$. The observed decrease in benzene insolubles is due to the generation (at lower temperatures) of isomeric trimers of indene ( $\alpha$-truxene and $\beta$-truxene or isotruxene) which are insoluble but which react at higher temperatures. (5) The abrupt increase in benzene insolubles and viscosity above $475^{\circ} \mathrm{C}$ corresponds to the formation of high-molecular-weight products and probably signals the initiation of mesophase formation.

Table 1

PROPERTIES OF INDENE POLYMERS PREPARED BY AUTOCLAVE TREATMENT

\begin{tabular}{|c|c|c|c|c|c|c|c|c|c|}
\hline \multirow[b]{3}{*}{$\begin{array}{l}\text { Sample } \\
\text { Number }(1)\end{array}$} & \multirow[b]{3}{*}{$\begin{array}{c}\text { Autoclave } \\
\text { Temperature } \\
\left({ }^{\circ} \mathrm{C}\right)\end{array}$} & \multirow[b]{3}{*}{$\begin{array}{c}\text { Autoclave } \\
\text { Pressure, } \\
\text { Initial/Maximum } \\
\text { (MPa) } \\
\end{array}$} & \multicolumn{4}{|c|}{ Product Properties } & \multirow{2}{*}{\multicolumn{3}{|c|}{$\begin{array}{l}\text { Product Properties after } \\
\text { Outgassing at } 100^{\circ} \mathrm{c}(2)\end{array}$}} \\
\hline & & & & & $\begin{array}{l}\text { Isotruxene } \\
\text { Content }\end{array}$ & & & & \\
\hline & & & $\begin{array}{l}\text { Viscosity } \\
(\mathrm{Pa} \cdot \mathrm{s}\rangle\end{array}$ & $\begin{array}{l}\text { Benzene } \\
\text { Insolubles } \\
\text { (wt \%) }\end{array}$ & $\begin{array}{c}\text { in Benzene } \\
\text { Insolubles } \\
\text { (wt \%) }\end{array}$ & $\begin{array}{l}\text { Coke } \\
\text { Yield } \\
\text { (wt \%) }\end{array}$ & $\begin{array}{l}\text { Weight } \\
\text { Loss } \\
(\%)\end{array}$ & $\begin{array}{l}\text { Melting } \\
\text { Range } \\
\left({ }^{\circ} \mathrm{C}\right)\end{array}$ & $\begin{array}{l}\text { Coke } \\
\text { Yield } \\
\text { (wt \%) }\end{array}$ \\
\hline$N-13-20$ & 400 & $6.9 / 12.4$ & $<0.050^{(3)}$ & 16 & 45 & - & - & . & - \\
\hline$N-13-21$ & 450 & $10.3 / 19.8$ & $0.080^{(3)}$ & 12 & 10 & $23^{(4)}$ & - & - & - \\
\hline$N-13-27$ & 460 & $10.3 / 25.5$ & $0.320^{(3)}$ & 10 & 9 & $30^{(4)}$ & - & - & - \\
\hline$N-13-28-B$ & 470 & $6.9 / 23.4$ & 0.880 & 5 & 9 & 37 & 25 & $40 \cdot 70$ & 52 \\
\hline$N-13-44$ & 475 & $6.9 / 29.6$ & 2.750 & 4 & - & 44 & 24 & $58 \cdot 80$ & 56 \\
\hline$N-13-45$ & 485 & $6.9 / 29.3$ & 26.800 & 21 & . & 52 & 25 & $75-105$ & 66 \\
\hline
\end{tabular}

(1) Polymers were prepared by heating $400 \mathrm{~g}$ samples of indene in a $1000 \mathrm{~cm}^{3}$ autoclave for one hour at the hold tomporaturo ( \pm 6 degreec).

(2) Vacuum outgassed for $\sim 24$ hours.

(3) Viscosity measured after removal of insolubles by filtration.

(4) Coke vield of liquid phase after removal of insolubles by filtration.

These fluid pitches retain a considerable volatile content and may be converted to low-melting solids by vacuum outgassing, losing about $25 \%$ in weight during the process. Corresponding increases in coke yields were significant, as noted in Table 1 and Figure 1. The primary volatile was indane $\left(\mathrm{CgH}_{10}\right)$ which is formed from indene due to auto oxidation-reduction reactions. (Isomeric truxenes are examples of the oxidation products.) Indane is quite stable and thus is residual in the product.

Changes in the molecular-size distribution due to vacuum outgassing are illustrated in Figure 2.

Nuclear magnetic resonance (NMR) data in Figure 3 allow a comparison to be made of the distinctly different nonaromatic proton distributions in indene, indane, isotruxene, and two 
indene polymers [one formed cataIytically (using $\mathrm{TiCl}_{4}$ as the cata|yst)(6) and one formed by autoclave polymerization, as in this study]. Absorption bands corrésponding to nonaromatic protons are well resolved for the autoclave polymer (Curve d) and are comparable to those observed for indane (Curve b). Collectively, NMR data suggest that: (1) electronic and bonding environments for nonaromatic protons in the pitch polymers are similar to those of indane; (2) there are a small number of selected bond types formed during polymerization (compare with complex distribution of nonaromatic protons in polymers formed catalytically in Curve e); (3) methylene groups that bridge unsaturated groups, as are observed for indene (Curve a) and isotruxene (Curve c), are not present in the pitch polymers, denoting that unsaturation in the tive-member rings no longer exists if indeed the rings themselves exist in the final prod= uct; (4) while $50 \%$ of the protons in indene are aromatic, $60 \%$ of the pitch polymer protons were aromatic; (5) $20-25 \%$ of the protons in the pitch polymer were methylenic or methyne protons on carbon atoms adjacent $(\alpha)$ to aromatic rings (a'methyl protons were not calculated), and (6) the average number of carbon atoms per alkyl substituent group was just under 2 (calculated value 1.85, using an empirical method designed for the analysis of petroleum products(7-9)). This latter fact is consistent with the visual observation of aliphatic proton distribution in Curve d of Figure 3 which shows most of the protons to be on carbons that are alpha or beta to the aromatic rings.

Figure 4 shows the microstructure of graphite produced from indene pitch. Corresponding cryslallugraphic data list an average interlayer spacing (do02) of $3.361 \AA$ and an average crystallite size $\left(L_{c}\right)$ of $700 \AA$. A g-factor (Maire and Mering $(10)$ ) of 0.93 was calculated for this specific sample, denoting a highly graphitic carbon.

Phenanthrene - Polymerization of phenanthrene was studied at autoclave temperatures of $450-515^{\circ} \mathrm{C}$. Heat-treatment times varied from 1 to 5 hours. Data are summarized in Table 


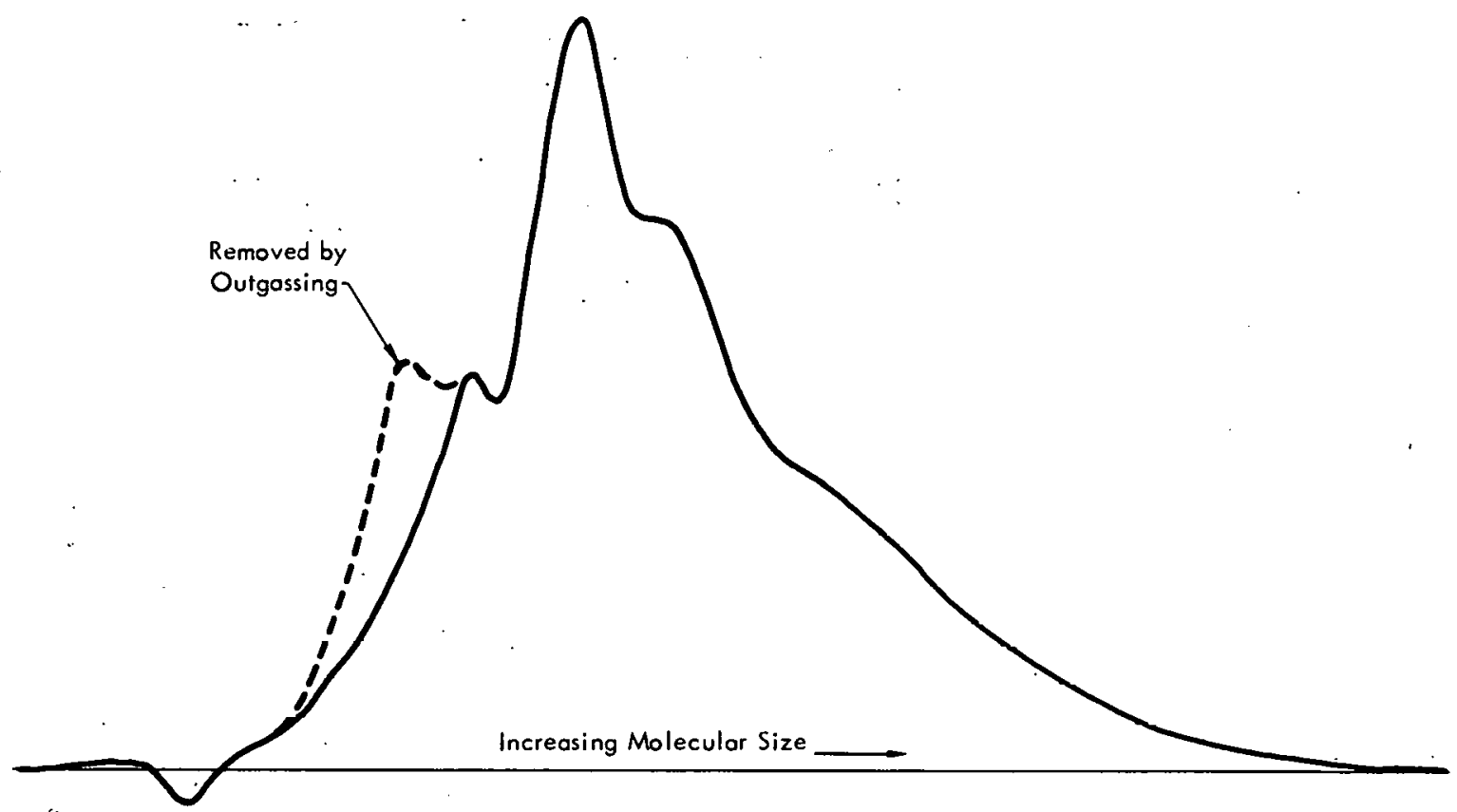

Figure 2. GEL-PERMEATION-CHROMATOGRAPHY SCAN OF THE INDENE POLYMER. (Produced in an Autoclave at $485^{\circ} \mathrm{C}$ Before and After Vacuum Outgassing at $100^{\circ} \mathrm{C}$; Sample N-13-45)

2. Temperatures approaching $500^{\circ} \mathrm{C}$ were required to effect polymerization. Heattreatment time in the temperature range from 500 to $515^{\circ} \mathrm{C}$ was a significant variable. One hour at $500^{\circ} \mathrm{C}$ proved to be insufficient while a five-hour period at this temperature was too" severe (produced an infusible phase). Figure 5 better shows the influence of time on the . product properties. Of the samples listed in. Table 2, one polymer product (Sample N-13-77) seemed to be usable as a low-melting pitch and suggests that useful products can be prepared by autoclave polymerization of phenanthrene under controlled conditions.

Table 2

PROPERTIES OF PHENANTHRENE POLYMERS PREPARED BY AUTOCLAVE HEAT TREATMENT

\begin{tabular}{|c|c|c|c|c|c|c|c|}
\hline $\begin{array}{c}\text { Sample } \\
\text { Number (1) }\end{array}$ & $\begin{array}{c}\text { Autoclave } \\
\text { Temperature } \\
\left(^{\circ} \mathrm{Cl}\right.\end{array}$ & $\begin{array}{l}\text { Reaction } \\
\text { Time } \\
\text { (hrs) }\end{array}$ & $\begin{array}{l}\text { Pressure, } \\
\text { Initial/Maximum } \\
\text { (MPa) }\end{array}$ & Product Description & $\begin{array}{l}\text { Melting } \\
\text { Range } \\
\left({ }^{\circ} \mathrm{C}\right)\end{array}$ & $\begin{array}{c}\text { Bènzzeñe } \\
\text { Insolubles } \\
(\%)\end{array}$ & $\begin{array}{l}\text { Coke } \\
\text { Yield } \\
\text { (\%) }\end{array}$ \\
\hline$N-13-54$ & 450 & 1 & $6.9 / 17.6$ & Unreacted Phenanthrene & $\sim 100$ & - & 1.0 \\
\hline$N-13-61$ & 475 & 1 & $6.9 / 18.3$ & Unreacted Phenanthrene & $\sim 100$ & - & - \\
\hline$N-13-62$ & 485 & 1 & $6.9 / 17.9$ & $\begin{array}{l}\text { Polymer + Unreacted } \\
\text { Phenanthrene }\end{array}$ & $38-60$ & . & - \\
\hline$N-13-63$ & 500 & 1 & $6.9 / 20.0$ & $\begin{array}{l}\text { Polymer + Unreacted } \\
\text { Phenanthrene }\end{array}$ & $40 \cdot 70$ & $\cdot$ & - \\
\hline$N-13-91$ & 500 & 5 & $6.9 / 19.5$ & $\begin{array}{l}\text { Polymer + Infusible } \\
\text { Phase }\end{array}$ & $100 \cdot>250$ & 81 & 57 \\
\hline $\begin{array}{l}\text { N-13-77 } \\
\because \cdots\end{array}$ & 515 & 1 & $6.9 / 22.1$ & $\begin{array}{l}\text { Polymer }+ \text { Small } \\
\text { Content Phenanthrene }\end{array}$ & $30-50$ & 27 & 44 \\
\hline $\mathrm{N}-13-89$ & 515 & 2 & $6.9 / 19.2$ & $\begin{array}{l}\text { Polymer + Infusible } \\
\text { Phase }\end{array}$ & $100->250$ & 59 & 54 \\
\hline$N-13-79$ & 515 & 5 & $6.9 / 20.1$ & Infusible. & $>250$ & 75 & 78 \\
\hline
\end{tabular}

(1) One-hundred-gram samples were heated in the $1000-\mathrm{cm}^{3}$ autoclave. 


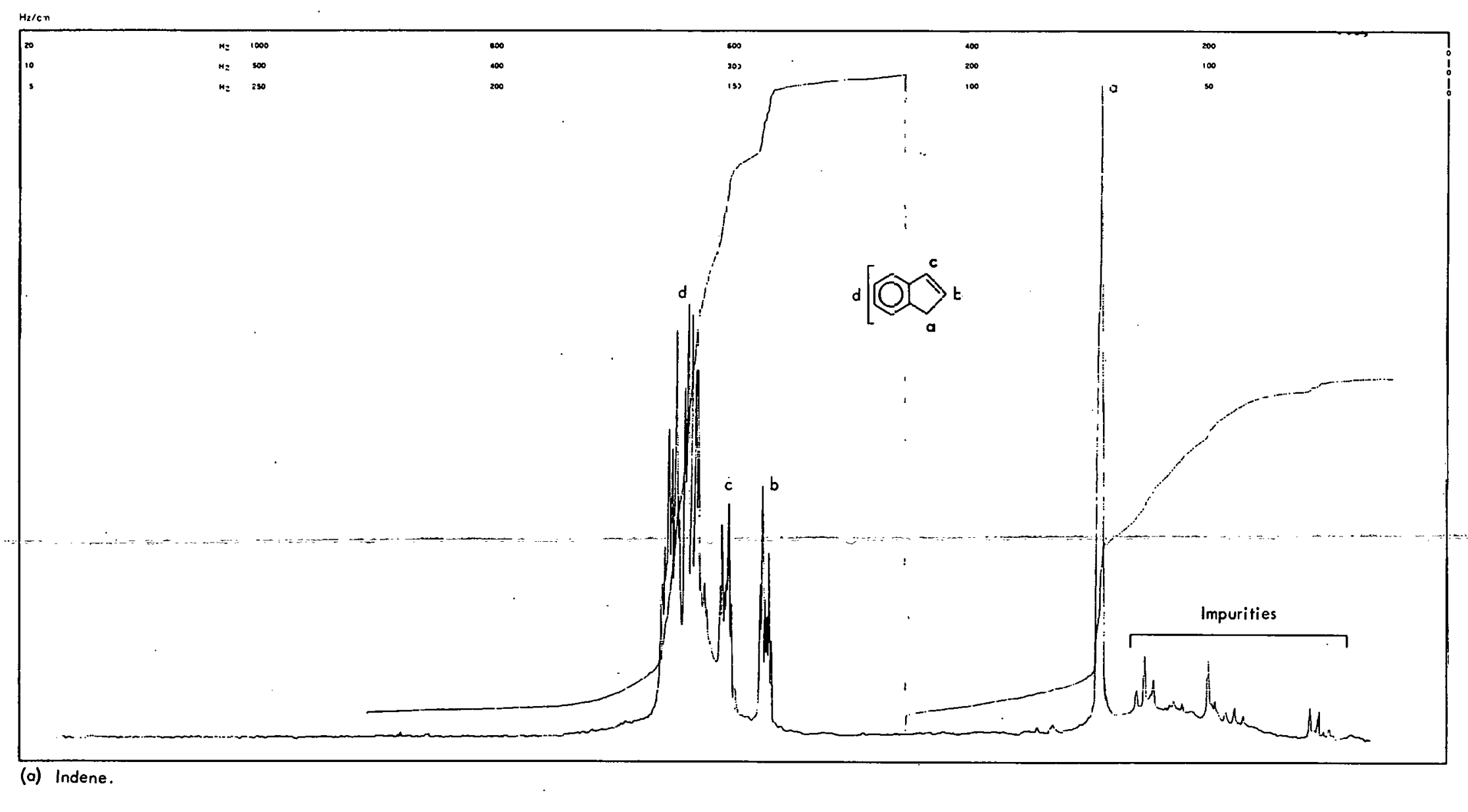

$\vec{N}$
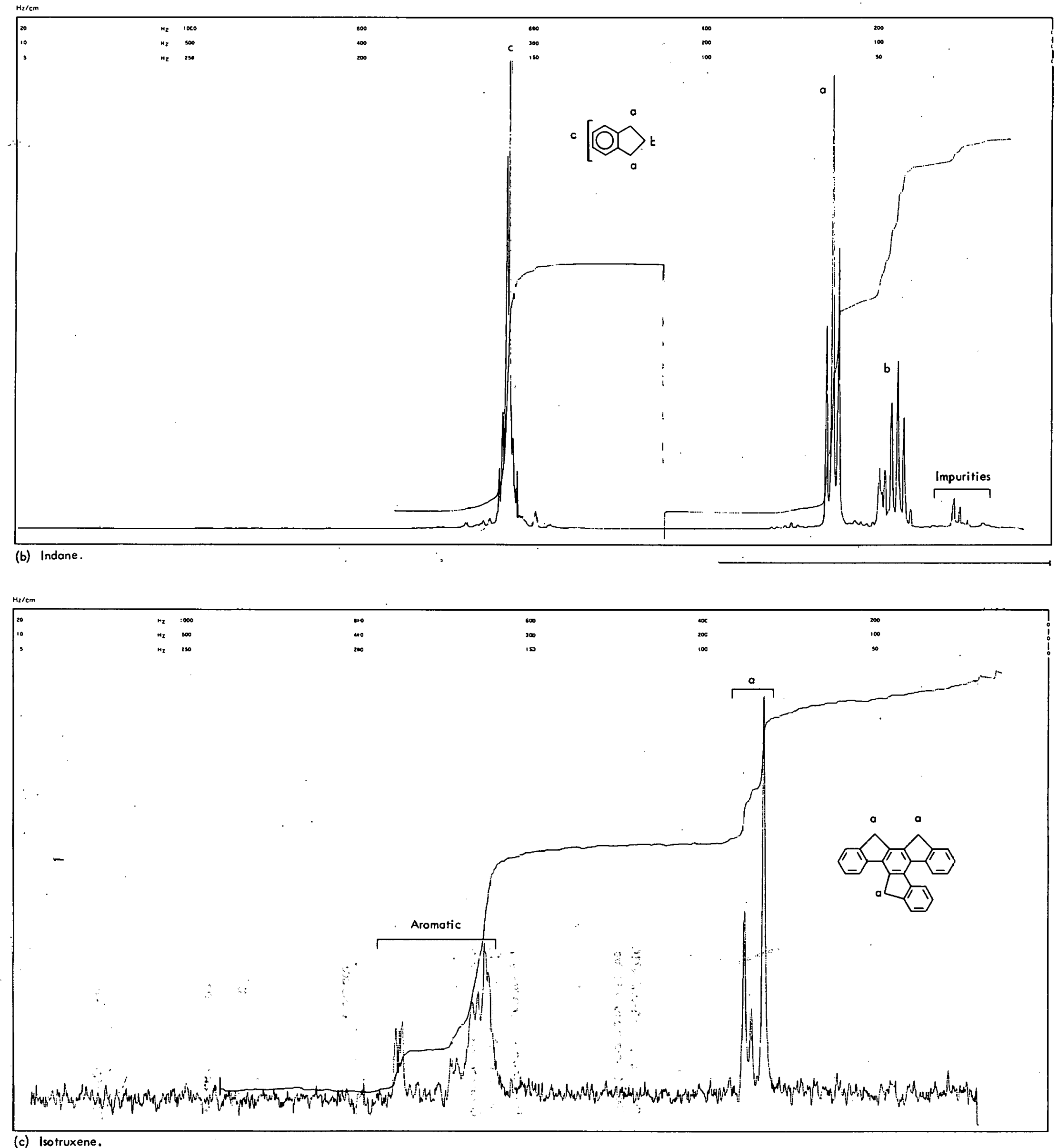

(c) Isotruxene 


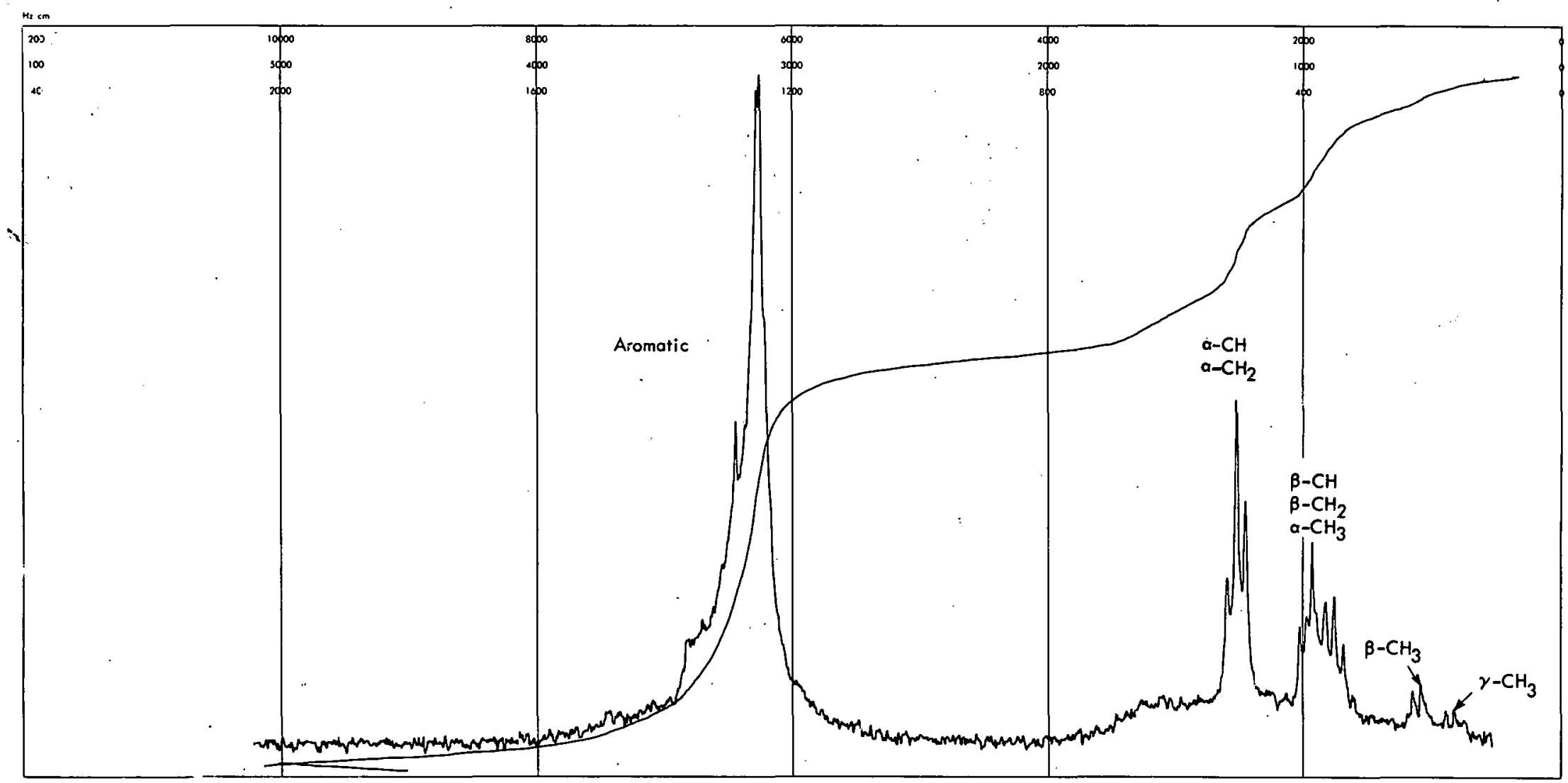

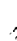

(d) Autoclave Polymer. (Jample $N-13-44$ )

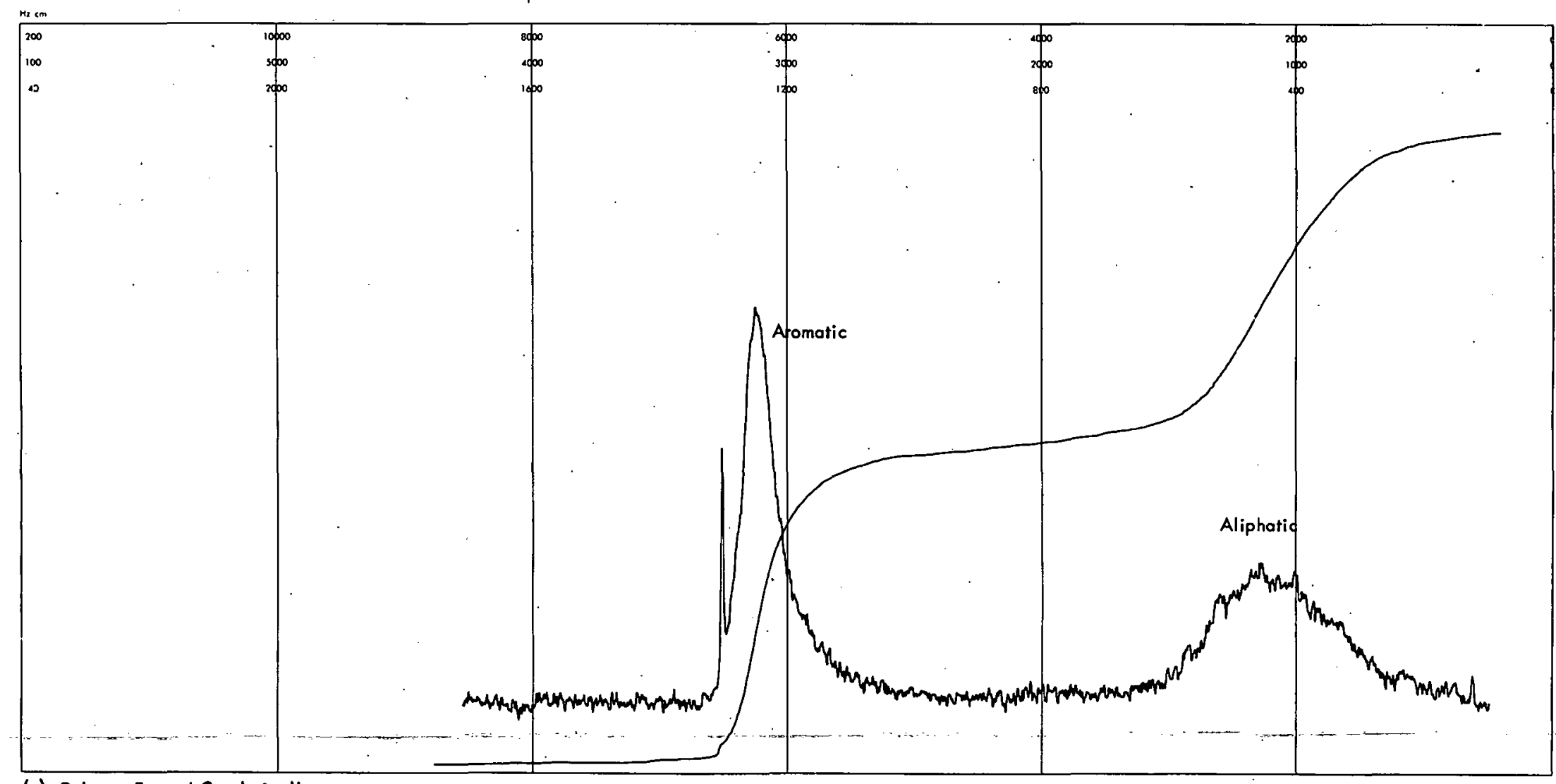

(e) Polymer Formed Catolytically.

Figure 3. NUCLEAR-MAGNETIC.RESONANCE SCANS, SHOWING PROTON DISTRIBUTIONS OF INDENE AND ITS DERIVATIVES. 


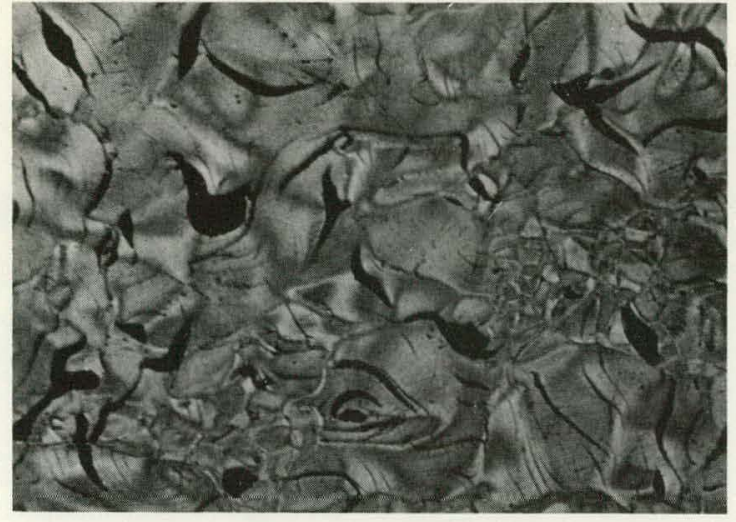

J395-1

Figure 4. MICROSTRUCTURE OF CARBON (AFTER $2800^{\circ}$ C) DERIVED FROM THE AUTOCLAVED POLYMER OF INDENE. (Sensitive Tint; 250X)

Carbon derived from phenanthrene polymers were graphitic, as noted by an example microstructure in Figure 6.

Triphenylbenzene - Polymers of 1,3,5-triphenylbenzene (TPB) were prepared by autoclave heat treatment in the temperature range from 500 to $5150 \mathrm{C}$. Data on four autoclave runs are presented in Table 3, and suggest that the heating time (in the range from 0 to 3 hours) had a greater impact on the polymer properties than did temperature (in the range from 500 to $515^{\circ} \mathrm{C}$ ). Properties (melting range and coke yield) of products after one hour at both 500 and $515^{\circ} \mathrm{C}$ are similar, while those after two and three hours at $515^{\circ} \mathrm{C}$ indicate significant advances in polymerization. This increase in the polymer content with heating time is also evident in Figure 7, which compares the molecular-size distributions after one and two hours at $515^{\circ} \mathrm{C}$.

After three hours at $515^{\circ} \mathrm{C}$, the product was heterogeneous, consisting of two polymeric phases (one fusible and one infusible). Carbons derived from the TPB polymers were nongraphitic.

Sample N-13-9? (Tahle 3) appeared to he the most usable as a binder. The polymer melted at approximately $1000 \mathrm{C}$, had a low benzene insoluble content, was relatively homngenenus, and had a coke yield of approximately 50 wt \%.

Indene/Triphenylbenzene Mixtures-Mixtures of indene and triphenylbenzene (TPB) were autoclave polymerized at temperatures of 440 to $4 / 0 \cup(\mathrm{C}$ to see it the properties of carbons derived from various combinations of these precursors could be correlated to the composition of the mixtures. As

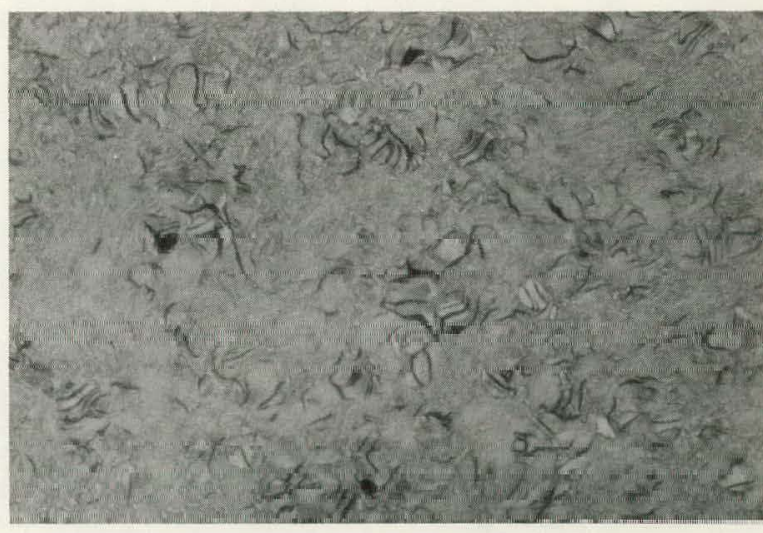

K390-1

Figure 6. MICROSTRUCTURE OF CARBON (AFTER $\left.900^{\circ} \mathrm{C}\right)$ THAT WAS DERIVED FROM AUTOCLAVED PHENANTHRENE. (Sensitive Tint: 100X) 
Table 3

PROPERTIES OF 1,3,5-TRIPHENYLBENZENE POLYMERS PREPARED BY AUTOCLAVE HEAT TREATMENT

\begin{tabular}{lcccccc}
\hline $\begin{array}{c}\text { Sample } \\
\text { Number }\end{array}$ & $\begin{array}{c}\text { Autoclave } \\
\text { Temperature } \\
\left({ }^{\circ} \mathrm{C}\right)\end{array}$ & $\begin{array}{c}\text { Reaction } \\
\text { Time } \\
(\mathrm{hrs})\end{array}$ & $\begin{array}{c}\text { Pressure, } \\
\text { Initial/Maximum } \\
(\mathrm{MPa})\end{array}$ & $\begin{array}{c}\text { Melting } \\
\text { Range } \\
\left({ }^{\circ} \mathrm{C}\right)\end{array}$ & $\begin{array}{c}\text { Benzene } \\
\text { Insolubles } \\
(\%)\end{array}$ & $\begin{array}{c}\text { Coke } \\
\text { Yield } \\
(\%)\end{array}$ \\
\hline $\mathrm{N}-13-80$ & $500^{(1)}$ & 1 & $6.9 / 18.7$ & $25-28(2)$ & $<0.1$ & 19 \\
$\mathrm{~N}-13-81$ & $515(1)$ & 1 & $6.9 / 18.3$ & $25-30^{(2)}$ & 2.0 & 23 \\
$\mathrm{~N}-13-92$ & $515(3)$ & 2 & $6.9 / 18.3$ & $72-110^{(2)}$ & 0.5 & 48 \\
$\mathrm{~N}-13-93$ & $515^{(3)}$ & 3 & $6.9 / 18.1$ & $100->250^{(4)}$ & 68 & 52 \\
\hline
\end{tabular}

(1) Fifty-gram samples were heated in the $1000-\mathrm{cm}^{3}$ autoclave.

(2) Products composed of both polymer and monomer phases.

(3) One-hundred-gram samples were heated in the $1000-\mathrm{cm}^{3}$ autoclave.

(4) Product contained heterogeneous polymeric phases.

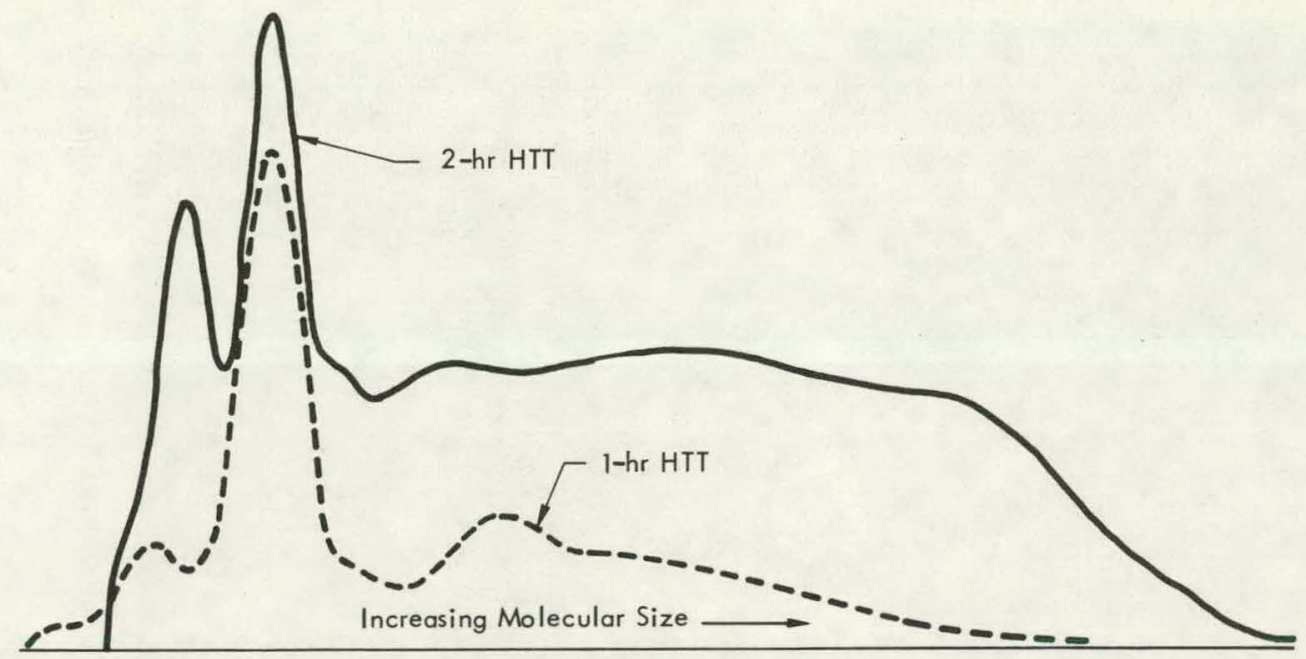

Figure 7. GEL-PERMEATION-CHROMATOGRAPHY SCANS, SHOWING MOLECULAR-SIZE DISTRIBUTIONS OF POLYMERS PREPARED BY THE AUTOCLAVE POLYMERIZATION OF 1,3,5-TRIPHENYLBENZENE. (At $515^{\circ} \mathrm{C}$ )

previously related, autoclaved polymers of indene alone produced graphitic carbons, while TPB polymers yielded nongraphitic carbons. Table 4 lists the data obtained on four indene/TPB compositions.

In general, the polymers were low-melting pitches with similar properties (melting ranges, benzene insolubles, and coke yields). However, the properties of carbon derived from the polymers were different and did show a correlation with the initial composition of the precursor mixture. This fact is evident in Figure 8 , which compares the microstructures of the resulting carbons.

Cinnamylideneindene/1,4-diphenyl-1,3-butadiyne Mixtures-Mixtures of cinnamylideneindene (CAI) and 1,4-diphenyl-1,3-butadiyne (dimerized phenylacetylene, or DPA) were autoclave polymerized at $340^{\circ} \mathrm{C}$ to see if carbon properties could be moditied in a 

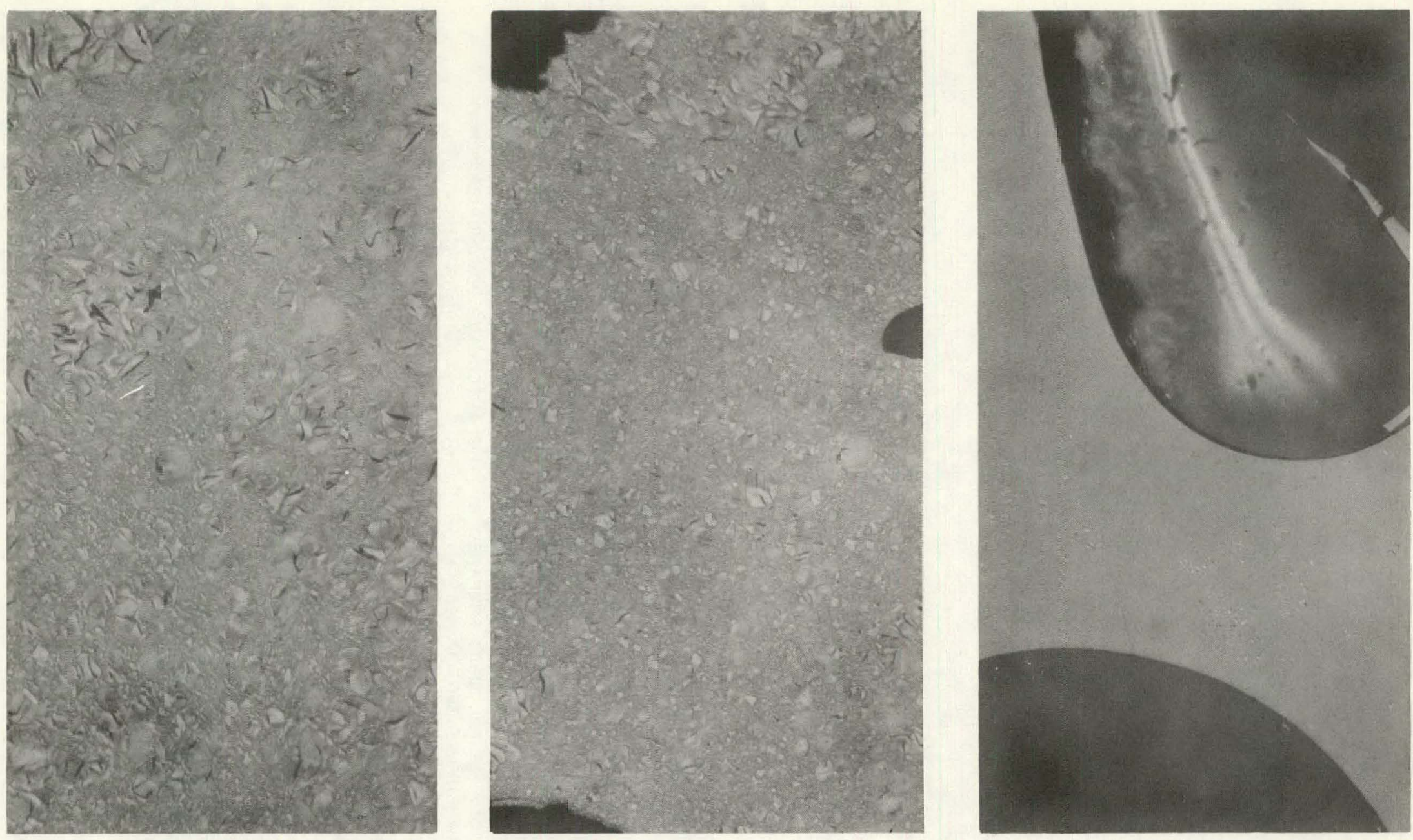

Figure 8. MICROSTRUCTURES OF CARBONS (AFTER $900^{\circ} \mathrm{C}$ ) CERIVED FRO ' BLENDS OF INDENE AND TR PHENYLBENZENE THAT WER $\equiv$ AUTOCLAVE POLYMERIZEC. (Sensitive Tint; 250X) 
Table 4

PROPERTIES OF POLYMERS PREPARED BY AUTOCLAVE HEAT TREATMENT OF INDENE/TRIPHENYLBENZENE MIXTURES

\begin{tabular}{ccccccc}
\hline $\begin{array}{c}\text { Sample } \\
\text { Number }(1)\end{array}$ & $\begin{array}{c}\text { Sample } \\
\text { Composition } \\
(w t \% \text { TPB })\end{array}$ & $\begin{array}{c}\text { Autoclave } \\
\text { Temperature } \\
\left({ }^{\circ} \mathrm{C}\right)\end{array}$ & $\begin{array}{c}\text { Pressure, } \\
\text { Initial/Maximum } \\
\text { (MPa) }\end{array}$ & $\begin{array}{c}\text { Polymer } \\
\text { Melting } \\
\text { Range } \\
\left({ }^{\circ} \mathrm{C}\right)\end{array}$ & $\begin{array}{c}\text { Benzene } \\
\text { Insolubles } \\
\text { (wt \%) }\end{array}$ & $\begin{array}{c}\text { Coke } \\
\text { Yield } \\
\text { (wt \%) }\end{array}$ \\
\hline N-14-52 & 5 & 450 & $6.9 / 19.3$ & $<30$ & 18.5 & 42 \\
N-14-50 & 15 & 440 & $6.9 / 18.6$ & $<30$ & 11.0 & 39 \\
N-14-51 & 15 & 450 & $6.9 / 19.3$ & $<30$ & 19.0 & 40 \\
N-14-53 & 25 & 470 & $6.9 / 20.0$ & $50-70$ & 23.0 & 45 \\
\hline
\end{tabular}

(1) One-hundred-gram samples (total weight) were heated in the $1000-\mathrm{cm}^{3}$ autoclave.

controlled fashion by blending a thermoplastic and a thermosetting polymer. CAI yields a thermoplastic polymer and a graphitic carbon,(11) while DPA yields a thermosetting polymer and a nongraphitic carbon. The thermogram in Figure 9 indicates that DPA initially melts $\left(\sim 80^{\circ} \mathrm{C}\right)$ and subsequently polymerizes $\left(\sim 200^{\circ} \mathrm{C}\right)$, and suggests that weight losses were predominantly associated with polymerization and pyrolysis reactions. Coke yields approaching 60 wt \% were obtained during thermal analysis.

Table 5 lists the data that were obtained on polymers and derived carbons for various precursor compositions. Note that the polymer melting temperatures increased with increasing DPA content, indicative of increased crosslinking. For the same reason, coke-yield values for the compositions studied increased in a near-linear fashion with increasing DPA content, as shown in

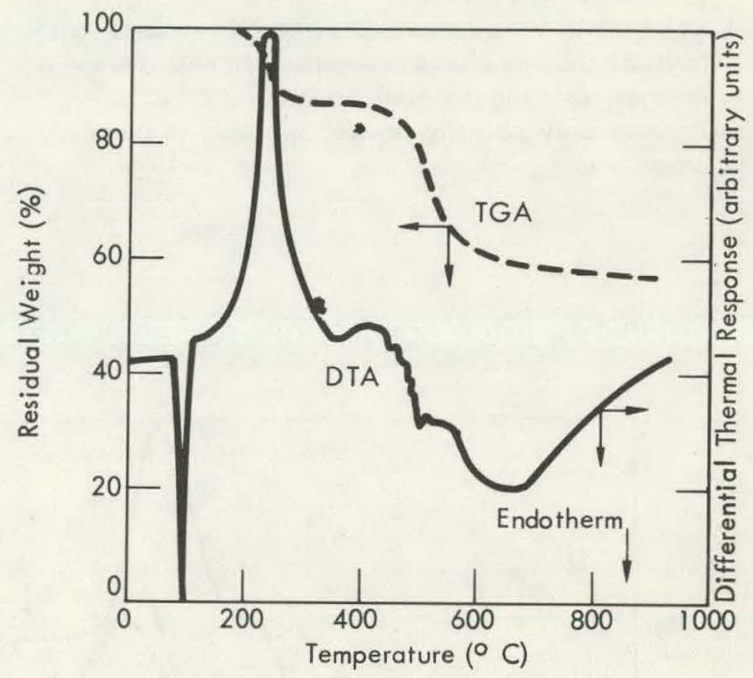

Figure 9. THERMOGRAM OF THE DIMER OF PHENYLACETYLENE. Figure 10. An additional indication of increased crosslinking with increasing DPA content was observed in GPC scans (Figure 11) which shows that average molecular sizes increase with increasing DPA content.

These strong correlations between precursor composition and product properties are also reflected in derived carbons. Carbon microstructures in Figure 12 show a significant decrease in graphitic character with increasing DPA content in the precursor.

\section{DISCUSSION OF RESULTS}

The results presented in this report are quite preliminary but do illustrate the feasibility and potential of synthetic pitch systems based on known starting materials and relatively simple processing techniques. Relative to pitches derived from fossil fuels, the major advantages of a synthetic pitch may be summarized as follows: 
Table 5

PROPERTIES OF THE COPOLYMERS OF CINNAMYLIDENEINDENE AND DIMERIZED PHENYLACETYLENE

\begin{tabular}{cccc}
\hline $\begin{array}{c}\text { Sample } \\
\text { Number(1) }\end{array}$ & $\begin{array}{c}\text { DPA } \\
\text { Content } \\
(w t \%)\end{array}$ & $\begin{array}{c}\text { Polymer } \\
\text { Melting } \\
\text { Range } \\
\left({ }^{\circ} \mathrm{C}\right)\end{array}$ & $\begin{array}{c}\text { Coke } \\
\text { Yield(2) } \\
(\%)\end{array}$ \\
\hline N-13-42-A & 0 & $72-86$ & 54 \\
N-13-42-B & 10 & $100-130$ & 61 \\
N-13-42-C & 20 & $130-160$ & 67 \\
N-13-42-D & 30 & $160-190$ & 73 \\
N-13-42-E & 40 & $180-230(3)$ & 85 \\
\hline
\end{tabular}

(1) Cinnamylideneindene (CAI) (71 ppm K) and dimerized phenylacetylene (DPA) were blended as powders and copolymerized by heat treatment for two hours at $340^{\circ} \mathrm{C}$ in a $1000-\mathrm{cm}^{3}$ autoclave $(\sim 5 \mathrm{MPa})$. Fortygram samples were used.

(2) Coke yields were calculated as percent residual char from 5-g samples after a rate-controlled heat treatment in argon requiring five hours to attain $900^{\circ} \mathrm{C}$.

(3) Polymer only partially melted; appeared to be highly crosslinked.

2. Organic-to-pitch conversions can be accomplished in a relatively simple, one-step process.

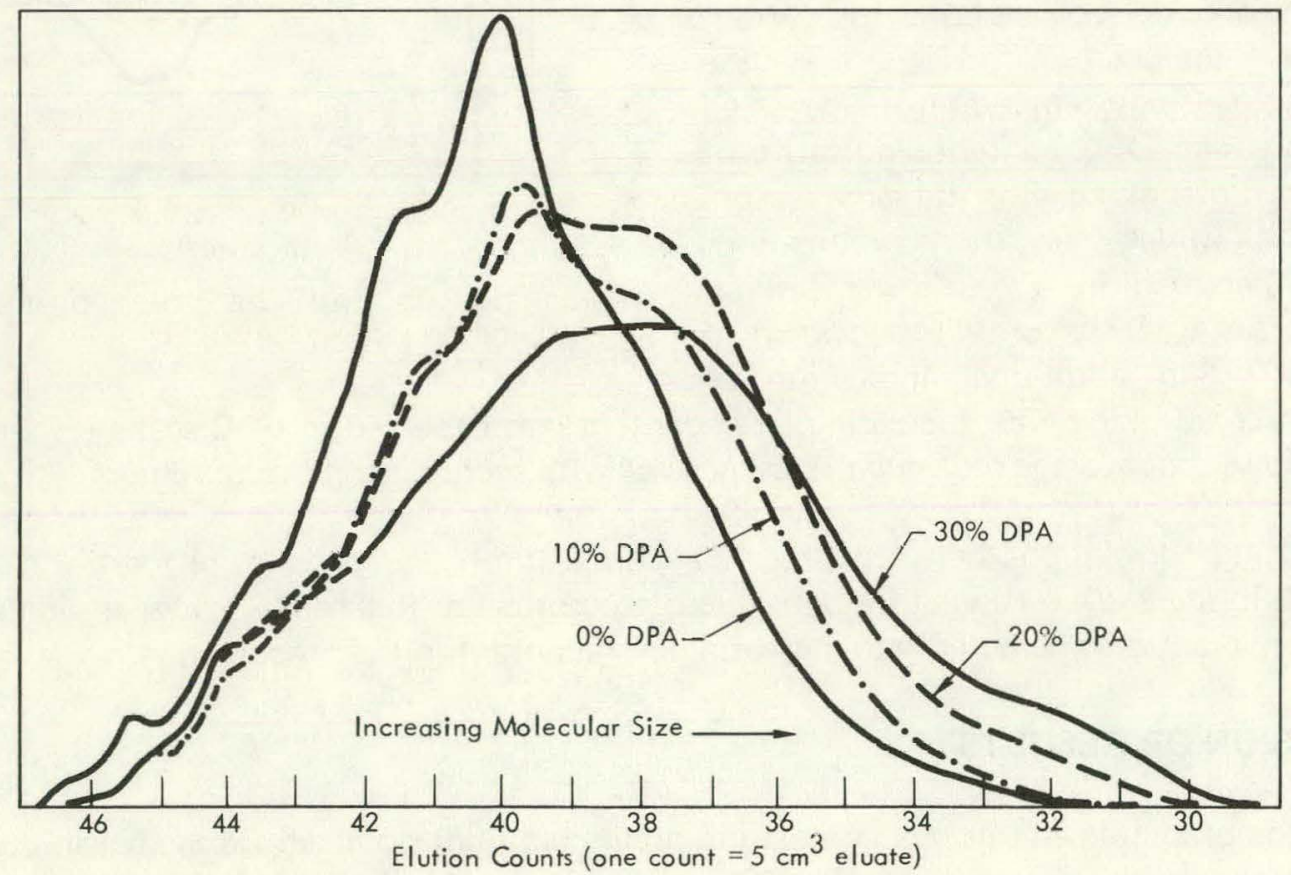

Figure 11. GEL-PERMEATION CHROMATOGRAMS OF THE COPOLYMERS OF CINNAMYLIDENEINDENE AND PHENYLACETYLENE DIMER AFTER AUTOCLAVE TREATMENT AT $340^{\circ} \mathrm{C}$.

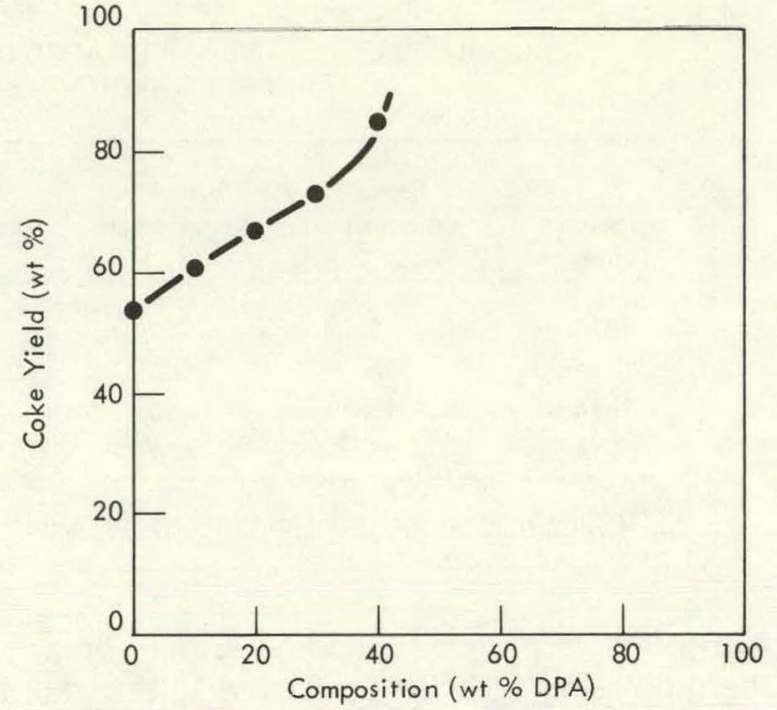

Figure 10. COKE YIELDS (AFTER $900^{\circ} \mathrm{C}$ ) OF POLYMERS PREPARED BY AUTOCLAVE HEAT TREAT. MENT $\left(340^{\circ} \mathrm{C}\right)$ OF CINNAMYLIDENEINDENE/1,4DIPHENYL-1,3-BUTADIYNE BLENDS.

1. System is based on simple, well-known organic compounds that are easily purified. 


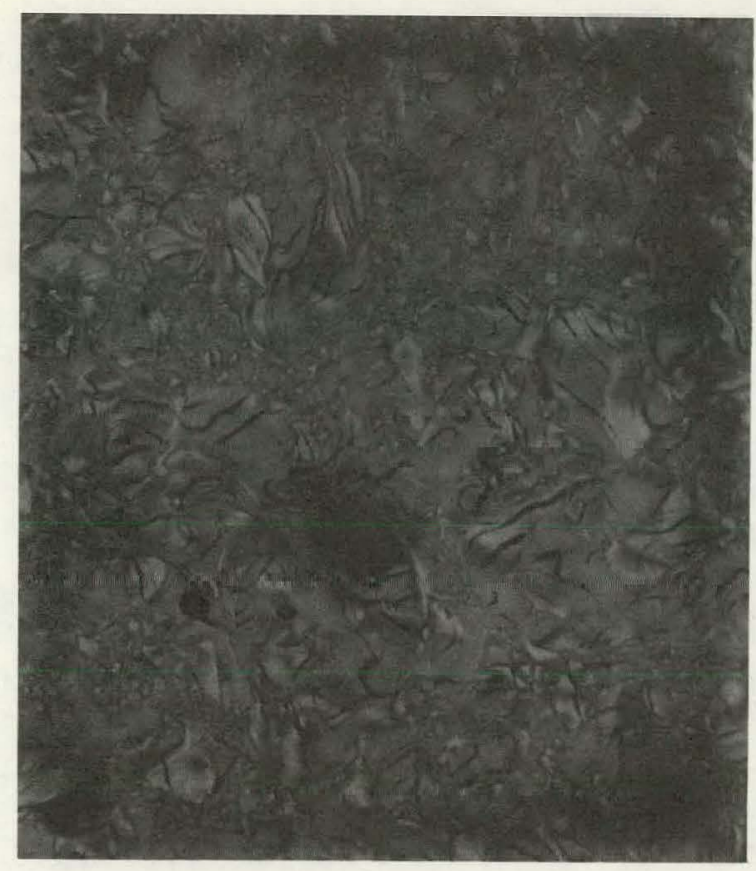

(a) Sample N-13-42-B, $10 \mathrm{Wt} \%$ DPA.

K52-3

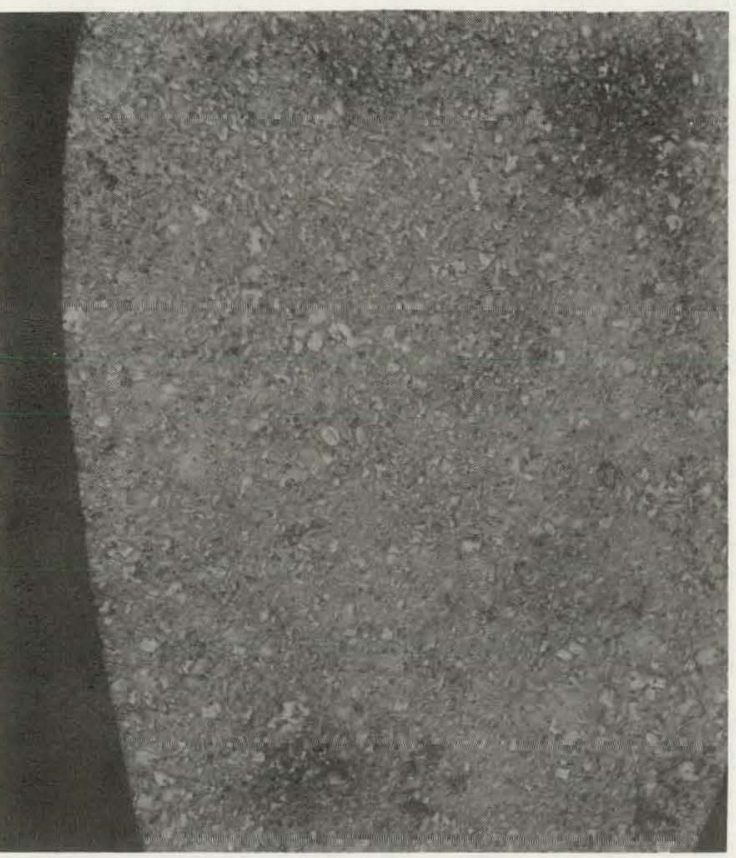

(c) Sample N-13-42-D, $30 \mathrm{Wt} \%$ DPA.

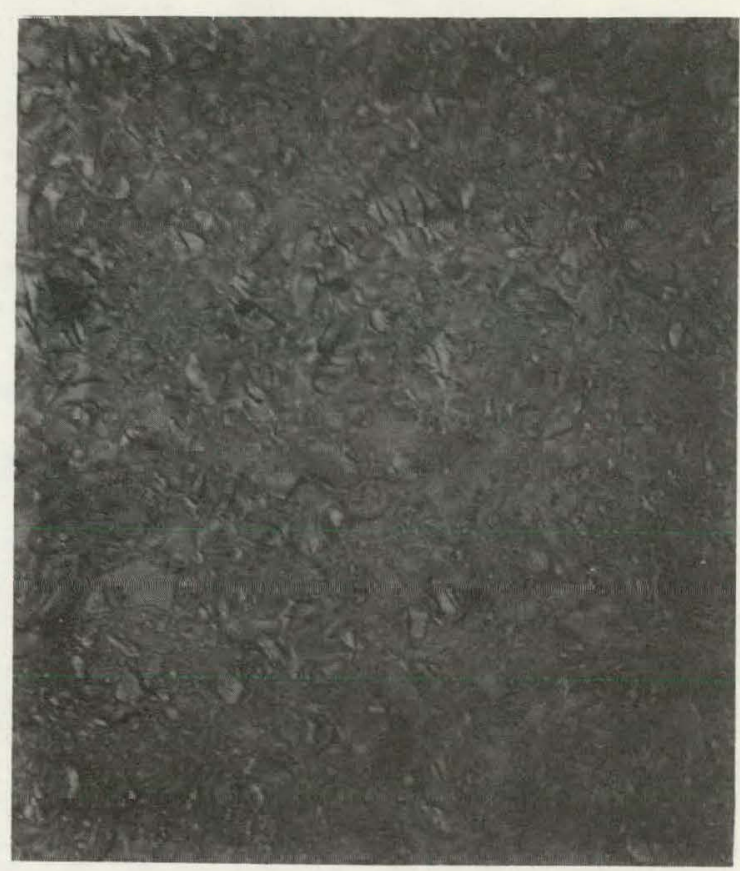

(b) Sample N-13-42-C, 20 Wt \% DPA.

K52-4

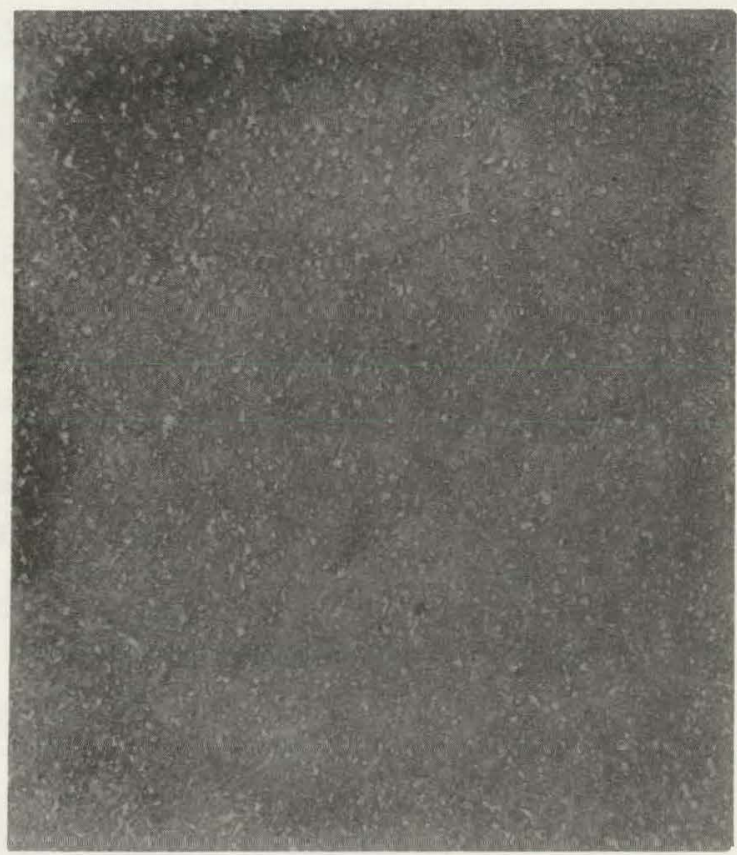

(d) Sample N-13-42-E, 40 Wt \% DPA.

K52-6

Figure 12. MICROSTRUCTURES OF CARBONS (AFTER $900^{\circ} \mathrm{C}$ ) DERIVED FROM BLENDS OF CINNAMYLIDENEINDENE AND 1,4-DIPHENYL-1,3-BUTADIYNE THAT WERE AUTOCLAVE POLYMERIZED AT $340^{\circ} \mathrm{C}$. (Sensitive Tint; 250X) 
3. No additives are required.

4. Ash content is negligible.

5. No sulfur or nitrogen content.

6. The polymerization processes can be understood and controlled.

7. Most important, such a system should offer a reproducible source of carbon.

A major disadvantage of such a system would be its cost unless, of course, specifications could not otherwise be met.

It should also be noted that polymerization reactions at or near the pyrnlysis temperatures, as was used in this study, necessitate close temperature control since reaction rates and the physical properties of the polymer are quite sensitive to temperature in this region.

In addition to the coke yield and the type of carbon produced, a major criterion for a usable pitch product is its processibility in binder applications which relate to such physical properties as melting temperature and homogeneity. As a result, many compounds evaluated under the conditions used in this cursory study yielded unsatisfactory products. Included in this list of compounds which are not detailed in this report were: acenaphthylene, anthracene, 2-methylnaphthalene, xylene (isomeric blend), 1,2,4,5-tetramethylbenzene, fluorene, 9-methylanthracene, 2-phenylnaphthalene, and 1,3-diethylbenzene.

From observations on the properties of the products that were studied, materials behavior was categorized as follows:

1. Those materials that polymerize at or near their pyrolysis temperatures in a manner similar to "cracking" reactions to produce a heterogeneous mixture of infusible products and unreacted starting material. Examples were methyl-substituted aromatics such as toluene, the xylenes, the methylnaphthalenes, and the methylanthracenes.

2. Those materials that react at lower temperatures $\left(<400^{\circ} \mathrm{C}\right)$ to produce high-molecularweight crystalline intermediates which are insoluble and are relatively stable to additional polymerization reactions. Such products are heterogeneous mixtures of crystalline cumpounds and isotropic polymers. Acenaphthylene behavior tended to fit this description due to the formation of decacyclene, fluoranthrene, and related structures. Indene also produces crystalline intermediates (isomeric truxenes), but they tend to react at higher temperalures.

3. Those materials with polymerization temperatures in the region where the formation of mesophase carbon (insoluble, infusible) also occurs, resulting in heterogeneous mixtures of isotropic and anisotropic polymer phases.

4. Those materials that produce relatively homogeneous pitch polymer.

Obviously, the ease and probability of obtaining homogeneous polymers decrease when two or more compounds are blended during polymerization. Differences in polymerization 
mechanisms and rates determine the degree and uniformity of interaction during polymerization and, thus, the homogeneity of the polymer.

Synthetic pitch systems detailed in this report fall into three classifications relative to carbon precursor applications: (1) single compounds that produce precursors to graphitic carbons; (2) single compounds that produce precursors to nongraphitic carbons; (3) binary mixtures of compounds that produce precursors to carbons having properties that can be correlated to the mixture composition.

Both indene and phenanthrene yield precursors to graphitic carbon. A more detailed study of polymer preparations and mechanical properties of prepared parts would be required to make a valid judgment on the utility of the two precursor systems. However, on the basis of data measured for usable products of each, properties of indene polymers were less sensitive to temperature during polymerization and seemed more desirable relative to melting temperatures, benzene insolubles, and coke yields.

Triphenylbenzene (TPB) yields a precursor to nongraphitic carbon which is consistent with the behavior of organics containing aromatic rings connected by a single bond. Examples are biphenyl, terphenyl, and the polyphenyls. However, TPB yields a thermoplastic rather than a thermosetting polymer and would seem suitable for some binder applications requiring a precursor to nongraphitic carbon. The low crystallinity of TPB-derived carbons is apparently due to a lack of planarity of aromatic rings in TPB polymers which prevents the proper molecular alignment required for mesophase formation and ultimately the three-dimensional crystalline lattice structure of graphite. TPB-derived carbons would be expected to have somewhat lower moduli than carbons derived from highly crosslinked, thermosetting polymers.

Both binary mixtures yielded precursors to carbons having graphitic properties that were a function of the composition of the binary blend. As such, both systems allow modification of their carbon properties in a controlled fashion. As noted for the individual compositions, relatively high temperatures were required to effectively polymerize mixtures of indene and TPB. It is not known to what extent indene and TPB interacted during polymerization, or to what to credit the modification in properties-to interaction or to mere dilution effects. If copolymerization, it is not of a crosslinking type. This conclusion can be ascertained from the thermoplastic nature of polymers from each component and from the fact that the physical properties of polymers from the blends are not greatly influenced by the initial composition.

On the other hand, physical properties of polymers from cinnamylideneindene (CAI)/1,4-diphenyl-1,3-butadiyne (OPA) blends were very much a function of composition, suggesting interaction of a crosslinking type during polymerization. Individually, CAl yields thermoplastic precursors to graphitic carbons, while DPA yields thermosetting polymers and nongraphitic carbons. Both $\mathrm{CAl}$ and DPA are quite reactive, and polymerization was effected at somewhat lower temperatures $\left(340^{\circ} \mathrm{C}\right)$.

In comparison, the indene/TPB system is derived from more common organic chemicals and has lower melting temperatures, while the CAI/DPA system requires lower autoclave temperatures, has a lower insoluble content, and has higher coke-yield values. 


\section{CONCLUSIONS AND RECOMMENDATIONS}

Production of synthetic pitches by autoclave polymerization of organics will require uniform temperatures within the working cavity and relatively close temperature control. Temperature values measured in this study should approximate that required to produce the designated products, but should not be associated with a high degree of accuracy. It is anticipated that each autoclave system would have to be calibrated anew relative to temperatures and product properties. Product uniformity and quality would be improved if the autoclave contents were agitated during the heat-treatment period.

A judgment on the merits of the specific pitches generated during this study would require test data on parts fabricated from these materials. Though synthetic pitches offer higher purity, greater reproducibility, and a method of controlled modification of carbon, an estimate of present and projected costs of both synthetic and natural pitches would permit an assessment of the advantages on an economic basis. For specifications that could not otherwise be met by natural pitches, methods described in this report could be utilized to develop pitches and carbons with more specific properties. 


\section{REFERENCES}

(1) Thiele, J:; "Ueher Kondensations Producte des Indens", Ber d Deutsch Chem Ges, 33 p 3395 .

(2) Smith, W. E., Napier, B., Jr, and Harper, W. L.; Preparation and Characterization of Hydrocarbon Derivatives of Indene, $Y$-1712; p 22; Union Carbide Corporation-Nuclear Division, Oak Ridge Y-12 Plant, Oak Ridge, Tennessee; April 21, 197.0.

(3) Smith. W: E.: Nerva Fuel Element Development Program. Summary Report-Carbons Derived from Organic Compounds, "Y-1868, pp 10, 23; Union Carbide Corporation-Nuclear Division, Oak Ridge Y-12 Plant, Oak Ridge, Tennessee; February 3, 1973.

(4) Smith, W. E., Horne, O. J, Napier; B., Jr, Larson, E. A., and Harper, W. L.; Properties of Carbon Derives from Indene Compounds, Y-1790, pp 37 -40; Union Carbide Corporation-Nuclear Division, Oak Ridge Y-12 Plant, Oak Ridge, Tennessee; September 15, 197.1.

(5) Smith, Napier, and Harper; Op Cit, p 60.

(6) Ibid, p 17

(7) Smith, W. E.; Horne, O. J., and Napier, B., Jr; Characterization and Reproducibility of Petroleum Pitches, Y-1921, pp 13, 42; Union Carbide Corporation-Nuclear Division, Oak Ridge Y-12 Plant, Oak Ridge, Tennessee; March 1, 1974.

(8) Williams, R. B.; "Symposium on Composition of Petroleum Oils, . Determination and Evaluation", ASTM Spec Tech Publication 224, pp 168-94 (1958).

(9) Clutter, D. R., et al; Anal Chemistry, 44, pp 1395 - 1405 (1972).

(10) Maire, J. and Mering, J.; Proceedings of the Fourth Carbon Conference, p 345; Pergamon Press, New York (1960).

(11) Smith, Horne, Napier, Larson, and Harper; Op Cit, pp 35 - 50. 
Distribution

Aerospace Corporation - EI Segundo

Barry, W. T.

Blaes, H. M.

Brelent, S.

McClelland, J. D.

McDonald, W. R.

Meyer, R. A.

Air Force Weapons Laboratory

Guiles, N. L.

Jenkins, $F$.

MacMullen, $W$.

Army Materials and Mechanics

Research Center

Dignan, J. $ト$.

Ashland Oil and Refining Company

Chapman,

Hoertz, C.

Newman, J.W.

Battelle Memorial Institute

Chard, W.

Niez, D.

Defense Nuclear Agency

A.tkins, M./DDST

Mercer, $B$.

Moulton, J./APAS

Department of the Navy

Stoessl, L./SPR-27201

Director of Defense Research

and Engineering

Persh, J.

Energy Research and Development Administration - Oak Ridge

Hickman, H. D.

Zachry, D. S., Jr
Fiber Materials, Inc

Cook, J.

Lachman, W.

General Electric-Reentry and

Environmental Systems Division

Hall, K.

Musckant, S.

Stover, E. R.

Great Lakes Research Corporation

Whittaker, M.P.

Gulf-General Atomic

Engle, G. B.

Lawrence Livermore Laboratory

Huger, $\mathrm{H}$.

Landingham, $R$.

Moon, D.

Nelson, W. E.

Lockheed Missile and Space Company

Vidoz, A.

Los Alamos Scientific Laboratory

Hoyt, H. C.

Wullliạms, .I M

McDonnell-Douglas Astronautice Company

Acne, $C$.

Penton, A.

NASA-Ames Research Center

Lundell, J. H.

Naval Air Systems Command

Schmidt, $H$.

Naval Surface Weapons Center

Barnet, F. R./Kaubek, F. J.

Gowen, L./Code 2302

Rester, D. O.

Rowe, $\mathrm{C}$. 
Naval Ordinance Systems Command

Kinna, M. A./ORD-0333A

Oak Ridge Gaseous Diffusion Plant

Stief. S. S.

Wilcox, W. J., Jr

Oak Ridge National Laboratory

Caputo, A. J.

Eatherly, W. P.

Weir, J. R., Jr

Oak Ridge Y-12 Plant

Ardary, Z. L.

Armstrong, R. C.

Briscoe, O.W.

Burditt, R. B.

Burkhart, L. E.

Davis, R. M.

Duggan, H. G.

Ebert, T. H.

Fraser, R. J.

Keith, A.

Kite, H. T.

Lambdin, $F$.

Marrow, G. B.

McLendon, J. D.

Mills, J. M., Jr

Napier, B., Jr (5)

Napier, J. M.

Peterson, G. R.

Phillips, L. R.

Pollock, C.

Schreyer, J. M.

Smith, R. D.

Smith, W. E. (5)

Taylor, A. J.

Valentine, C. K.

Weathershy, W. F.

Williams, R. D.

Yaggi, W. J./Googin, J.. M.

Y-12 Central Files (5)

$Y-12$ Central Files (master copy)
Y-12 Central Files (route)

$Y-12$ Central Files $(Y-12 R C)$

Paducah Gaseous Diffusion Plant

Levin, R. W.

Penn State University

Walker, P. L., Jr

Samso

Elliott, $M$.

Logan, C.

Sandia - Albuquerque

Auerback, I.

Zimmerman J.C.

Sandia - Livermore

Rychnovsky, R: E.

Union Carbide Corporation-Carbon Products Division

Browning, J. B.

Singer, $L$.

Townsend, H. N.

Union Carbide Corporation-Chemical and Plastics Division

Shechter, L.

Union Carbide Corporation-Parma

Research Center

Chambers, W. E.

University of Tennessee-College

of Engineering

Stansbury, E. E.

Wright-Patterson Air Force Base

Keck, $\mathrm{H}$.

Latva, ... D.

Materne, H. A.

Pratt, C.

Schmidt,

In addition, this report is distributed in accordance with the category UC-25, Materials, as given in the USERDA Standard Distribution Lists for Unclassified Scientific and Technical Reports, TID-4500. 